\title{
Rapid microbial degradation of phenolic materials in California (USA) coastal environments
}

\author{
Thomas J. Boyd*, A. F. Carlucci \\ 0218, Marine Life Research Group, Scripps Institution of Oceanography, University of California at San Diego, La Jolla, \\ California 92093-0218, USA
}

\begin{abstract}
Phenolic materials are common in terrestrial and freshwater environments, yet their distribution is limited in marine systems. Since these compounds are common pollutants as well as important structural components of terrestrial and riverine humic materials, we used a phenolic model compound for the study of organic carbon dynamics in coastal environments. Concentrations and microbial utilization rates of $p$-cresol were determined in various waters off the coast of California, USA. Levels of $p$-cresol ranged from $9.26 \mathrm{ng} \mathrm{l^{-1 }}$ in Humboldt Bay in Northern California to $303 \mathrm{ng} \mathrm{l}^{-1}$ near the White's Point Outfall in Southern California. Levels of 37.1 to $61.1 \mathrm{ng} \mathrm{l}^{-1}$ were found at 3 other sampling locations in San Diego Bay and San Francisco Bay. Microbial utilization rates of $p$-cresol were determined by measuring cellular incorporation and respiration of ${ }^{3} \mathrm{H}-p$-cresol. Utilization rates ranged between 1.02 (Spanish Landing in San Diego Bay) and $35.5 \mathrm{ng} \mathrm{l}^{-1} \mathrm{~h}^{-1}$ (San Francisco Bay). Residence times for added tracer ranged from 10 (San Francisco Bay) to $28 \mathrm{~h}$ (at White's Point Outfall). Turnover times calculated from biodegradation rate and ambient concentration of $p$-cresol ranged from $1.7 \mathrm{~h}$ (San Francisco Bay) to $37 \mathrm{~h}$ (Spanish Landing in San Diego Bay). These rapid turnover times indicate high anthropogenic input of $p$-cresol and possibly natural input as a component of humic type materials. In areas where freshwater input is significant, utilization kinetics may suggest biodegradation of more complex, phenol-containing humic materials. We conclude that accumulation of phenols is not generally observed in coastal waters a short distance from input sources due to rapid microbial utilization
\end{abstract}

KEY WORDS: Phenolics · Utilization · Rate $\cdot$ Turnover · Coastal

\section{INTRODUCTION}

Phenolic materials are found in many environments. They may be naturally derived in ligneous materials (Knuutinen \& Mannila 1991), freshwater and marine sediments (King 1986, 1988, Abrahamsson \& Klick 1991, Charriere et al. 1991), marine microlayers (Carlson \& Mayer 1980, Carlson 1982), algae (Kozitskaya 1984, Steinberg 1989), and soil and freshwater humic material (Meyers-Schulte \& Hedges 1986. Malcolm 1990). Humic materials have sparked considerable interest from geochemists due to their biologically recalcitrant nature and their relatively undefined role

\footnotetext{
-Present address: Code 6115, EQSS, US Naval Research Laboratory, 4555 Overlook Avenue, Washington, DC 20375, USA. E-mail: tboyd@ccf.nrl.navy.mil
}

in balancing carbon budgets for riverine organic carbon (OC) input to the sea (Deuser 1988). There is considerable evidence to suggest that phenolic materials may be an integral part of humic materials in terrestrial and freshwater ecosystems (Ertel et al. 1986, Kalinowski \& Blondeau 1986, Knuutinen \& Mannila 1991, Marley et al. 1992). However, it is generally believed that phenolic moieties play a relatively minor role in the structure of marine humic materials, even in most coastal environments (Meyers-Schulte \& Hedges 1986, Malcolm 1990). Furthermore, the terrestrial signature in marine water and sediments is small when one considers the amount of OC transported by riverine systems into the coastal ocean (Steinberg et al. 1987, Ittekkot \& Haake 1990, Mulholland \& Olsen 1992). Evidence from ${ }^{13} \mathrm{C}$ ratios indicates that humic materials in marine waters are primarily the result of in situ processes, even in areas where riverine input is high. 
Chemical moieties such as components of vascular plant debris (Goni \& Hedges 1990) and sterols (Jasper $\&$ Caggosian 1993) have been used in the past as molecular tracers for indicating terrestrially derived $O C$. Because humic materials from freshwater sources exhibit considerable phenolic character, while those of marine origin show almost none, we have chosen phenolics as possible tracer compounds for the study of coastal OC dynamics.

In addition to natural phenolic material inputs, anthropogenic sources of phenols account for over $15 \mathrm{Gg} \mathrm{yr}^{-1}$ (1988-1990 data) in Califormia, USA (US EPA 1992). These data represent ocean and stream outfalls, and public owned treatment works (POTW) transfer estimates. Air releases are even higher and account tor over $100 \mathrm{Gg} \mathrm{yr}^{-1}$, although there are ilttie published data estimating how much eventually ends up in runoff. Catechols, substituted catechols, phenols and cresols are the major phenolics involved in water disposal, most of which are disposed of directly into the ocean or streams (US EPA 1992)

There are few studies in which biodegradation rates for phenolic materials have been determined in estuarine and marine systems (Bartholomew \& Pfaender 1983, Palumbo et al. 1988). In these studies, ${ }^{14} \mathrm{C}$ labeled substrates were added to natural water samples and uptake kinetics were determined from the production of ${ }^{14} \mathrm{CO}_{2}$. Substrates were added at various concentrations, and for purposes of determining utilization rates, the ambient concentrations were assumed to be negligible. We have attempted to approach these rate measurements from the opposite angle by specifically targeting areas where phenolic input is suspected and where ambient concentrations can be determined using scaled-up extraction techniques (Boyd 1994). By using ${ }^{3} \mathrm{H}$-labeled substrate having specific activity several orders of magnitude higher than the ${ }^{14} \mathrm{C}$-labeled counterpart, incubations could be carried out at true 'tracer' levels with the assumption that added tracer concentrations were negligible compared to ambient substrates (Boyd \& Carlucci 1994). Using a mass balance approach to determine the fate of added isotope and calculating isotope dilution from ambient substrate concentration, we report here rapid rates of microbial biodegradation of $p$-cresol and discuss possible ecological and biogeochemical significance of its degradation in representative coastal marine environments off the Califormia coast.

\section{MATERIALS AND METHODS}

Sampling sites. Locations of coastal California sampling sites are shown in Fig. 1. The sample sites were chosen to represent a range of marine to freshwater and terrestrially influenced estuaries. All samples were collected in June 1993. Sweetwater Channel in San Diego Bay is the site with the highest summer salinities ( 34 to $35 \%$ ) and probably receives most of its phenolic input from industrial dischargers located in the South Bay. Spanish Landing (also in San Diego Bay) is closer to the ocean and is more influenced by tidal flushing. This site is also characterized by a large recreational boating marina which, at least during summer, is the likely source of phenolic input (South Bay Dischargers 1990, 1991, 1992). White's Point Outfall represents a marine site, but is characterized by a large point input of terrestrially derived organic matter in the form of wastewater (from Los Angeles County). San Francisco Bay is the largest estuary on the west coast of the united States and is characterized by large fiesilwaiel inputs (Sacramento and San Joaquin Rivers) as well as considerable wastewater inputs from over 75 municipal and industrial dischargers (B. Thomson, Aquatic Habitat Institute, San Francisco, pers comm. 1993). Strong currents, mixing, and wind driven events are common and influence the chemistry of Bay waters. Humboldt Bay, like San Francisco Bay, is influenced by freshwater input (Mad River). Secondary sewage treatment and lack of significant industrial dischargers probably lead to low levels of simple phenolics in these waters.

All samples except that from White's Point Outfall were taken with 191 stainless steel containers (The Cornelius Company, Anoka, MN, USA) fitted with Teflon o-rings and seals and pretreated with $10 \%$ nitric acid, Milli- ${ }^{\otimes}$ water, and methanol rinses. A small boat was used for sampling the Sweetwater Channel and Spanish Landing sites. Sample containers were lowered over the side using polypropylene line and a lead weighted aluminum harness. Containers were allowed to equilibrate for $10 \mathrm{~min}$ at depth after which the lids were opened manually. Once filled, the containers were recapped at depth and immediately returned to the surface. Samples in San Francisco Bay, taken off a jetty, and in Humboldt Bay, taken off a dock, were collected by immersing the stainless steel container at the surface and filling directly. Contamination in all cases was kept to a minimum by covering prewashed containers with plastic bags until ready for deployment. The White's Point Outfall sample was taken aboard the RV 'Ocean Sentinel' in a $30 \mathrm{l}$ (precleaned with methanol and Milli-Q water) Niskin Bottle (National Oceanics, Miami, FL, USA) at $32 \mathrm{~m}$ within the waste plume and immediately transferred to the 19 l stainless steel containers. Methanol rinses from polyvinylchloride Niskin bottles were analyzed for contaminant leaching using GC/MS parameters described below and only 1 identifiable contaminating peak (diethylphthalate) was detected 

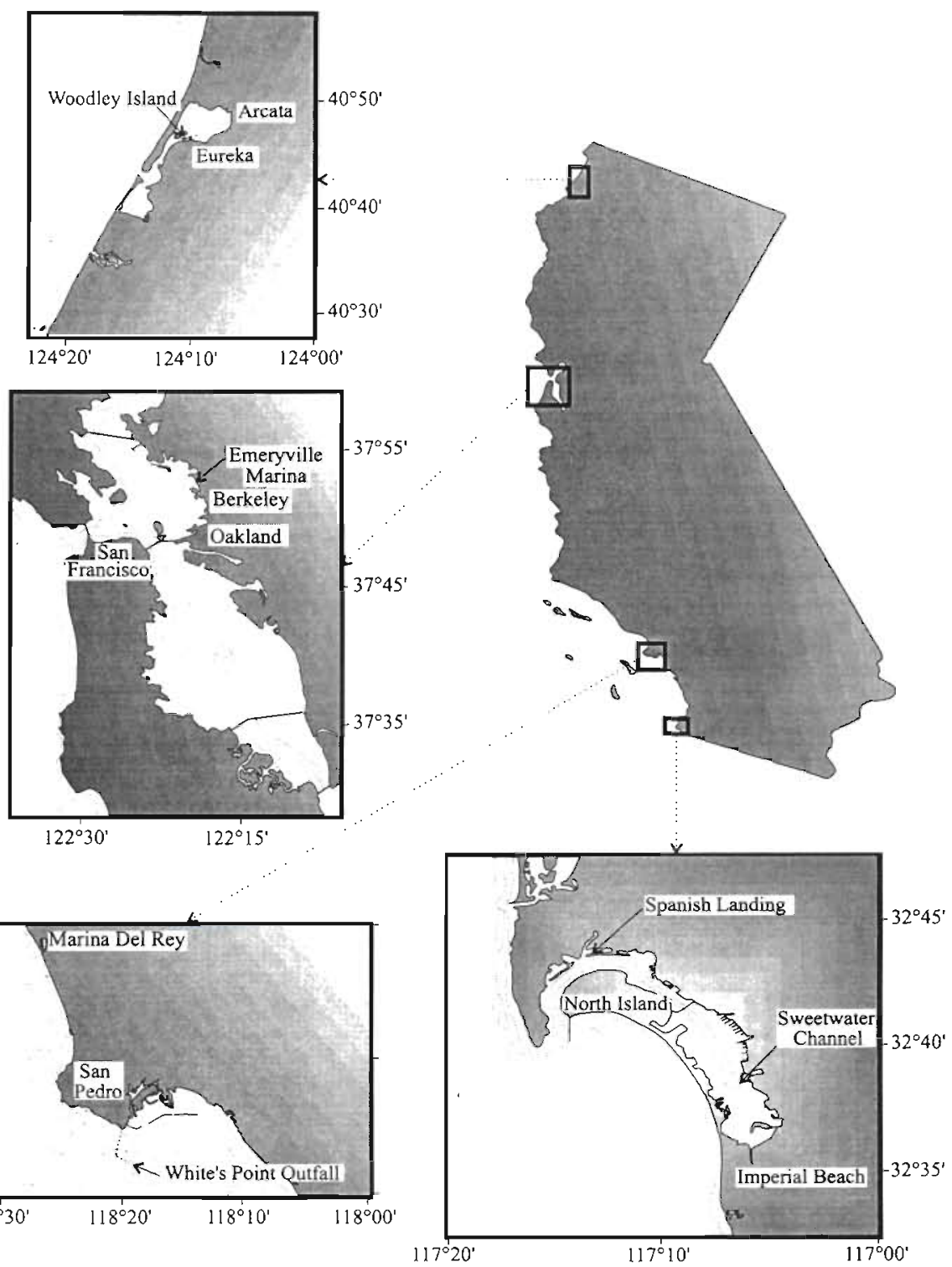

Fig. 1. California (USA) sampling sites

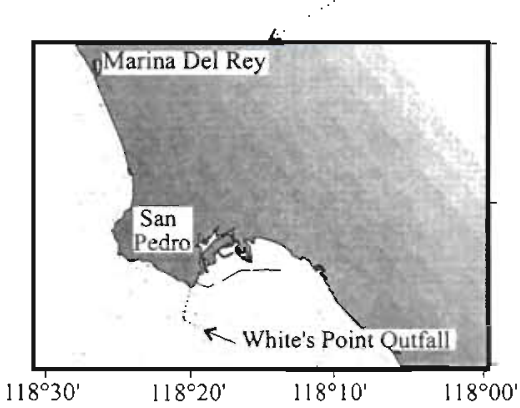

$117^{\circ} 20^{\circ}$

Chemicals. Acetic anhydride, methanol, 2,7-dihydroxynaphthalene, and anhydrous $\mathrm{NaSO}_{4}$ were of HPLC (high-performance liquid chromatography) grade and purchased from Fisher Scientific, Tustin, CA. $\mathrm{NaHCO}_{3}$ was also obtained from Fisher Scientific and was purified by leaching with 35 volumes of $\mathrm{CH}_{2} \mathrm{Cl}_{2}$ (Fisher Scientific) in a soxhlet extractor prior to use. Butylated hydroxytoluene was purchased from Sigma Chemical Corporation (St. Louis, MO, USA). $\mathrm{NaSO}_{4}$ was used for drying organic extracts and was pre-baked at $550^{\circ} \mathrm{C}$. Formalin (Fisher Scientific) was buffered with $\mathrm{Na}_{2} \mathrm{~B}_{4} \mathrm{O}_{7} \cdot 10 \mathrm{H}_{2} \mathrm{O}\left(80 \mathrm{~g} \mathrm{l}^{-1}\right.$; Mallinckrodt, Inc., St. Louis, $\mathrm{MO}$ ) and filtered through a $0.22 \mu \mathrm{m}$ type PH filter (Millipore Corp., Bedford, MA, USA) prior to use. Scintillation cocktail was Ecoscint (National Diag- nostics, Manville, NJ, USA). Water used in the preparation of standards was HPLC grade obtained from a Milli-Q purification apparatus (Millipore). $\left[2,6-{ }^{3} \mathrm{H}\right]-p-$ Cresol was obtained from Amersham Corp. (A.rlington Heights, IL, USA) as a crude preparation (see below for purification protocol).

Instrumentation and procedures. A Hewlett-Packard 5988 Chemstation gas chromatograph/mass spectrometer (GC/MS) with 7673A autosampler was used for phenolic analysis. An AT-35 (65\% methyl/35\% phenyl) glass capillary column, $25 \mathrm{~m}, 0.25 \mathrm{~mm}$ ID (Alltech Associates, Inc. Deerfield, IL) was used for all sample extracts. A sample volume of $3 \mu \mathrm{l}$ was used for each injection. The operating conditions were: column temperature $40^{\circ} \mathrm{C}$, hold $6 \mathrm{~min}, 40^{\circ} \mathrm{C}$ to $275^{\circ} \mathrm{C}$ at $5^{\circ} \mathrm{C}$ 
$\mathrm{min}^{-1}$, hold $5 \mathrm{~min}$; Injector port temperature $190^{\circ} \mathrm{C}$, linear velocity $40 \mathrm{~cm} \mathrm{~s}^{-1}$ (set at $150^{\circ} \mathrm{C}$ ), He, mass spectrum with electron impact source tuned with perfluorotributylamine (PFTBA), source temperature $180^{\circ} \mathrm{C}$, scan 50 to 500 amu (atomic mass units) with 100 abundance threshold, splitless injection. A $1 \mathrm{~g} \mathrm{l}^{-1}$ solution of butylated hydroxytoluene was used as an external standard for day-to-day calibration of the instrument.

A crude preparation (which proved relatively pure) of $\left[2,6-{ }^{3} \mathrm{H}\right]$-p-cresol was purified by HPLC using a Perkin-Elmer Series 410 LC pump, Wescan model 272 UV absorbance detector (Japan Spectroscopic Co., Ltd), and a Hewlett-Packard model 3390A integrator. A Waters Nova-Pak $\mathrm{C}_{18}, 4 \mu \mathrm{m}$ particle, $3.9 \times$ $150 \mathrm{~mm}$ steel column was employed for the purification. The operating conditions were: 0 min, $95 \% \mathrm{H}_{2} \mathrm{O}$ (1\% acetic acid) $/ 5 \% \mathrm{MeOH}$ ( $1 \%$ acetic acid), hold 2 min; 2 to 5 min ramp to $65 \% \mathrm{H}_{2} \mathrm{O} / 35 \% \mathrm{MeOH}$, hold $10 \mathrm{~min}$; detector set to $280 \mathrm{~nm}$ absorbance. Collected fractions of $\left[2,6-{ }^{3} \mathrm{H}\right]-p$-cresol were quantified by integration and the specific activity (11 $\left.\mathrm{Ci} \mathrm{mmol}{ }^{-1}\right)$ was calculated by radioassaying ${ }^{3} \mathrm{H}$ in a Beckman model LS1801 scintillation counter (Beckman Instruments, Irvine, CA).

Extraction and analysis of phenols were performed on single $19 \mathrm{l}$ samples as previously reported (Boyd 1994). Utilization, uptake and turnover of $\left[2,6-{ }^{3} \mathrm{H}\right]-p$ cresol were determined using triplicate $6 \mathrm{~h}$ incubations with $3 \mathrm{ng} \mathrm{l}^{-1}$ additions of $\left[2,6-{ }^{3} \mathrm{H}\right]$-p-cresol as previously described (Boyd \& Carlucci 1994). This method allows for determination of the fate of all added isotope such that a mass balance can be calculated from 3 fractions: cellular, unutilized substrate + extractable intermediates, and ${ }^{3} \mathrm{H}_{2} \mathrm{O}+$ unextractable intermediates. DPM (disintegrations per minute) values from isotope fractions were converted to $g\left[2,6-{ }^{3} \mathrm{H}\right]-p$-cresol by using the specific activity $11 \mathrm{Ci} \mathrm{mmol}{ }^{-1}$. Calculation of utilization kinetics was performed by addition of uptake (cellular) and respiration values (converted to $\mathrm{g}$ $\mathrm{l}^{-1} \mathrm{~h}^{-1}$ ) and calculating isotope dilution (i.e. $\left[2,6{ }^{3} \mathrm{H}\right]-p-$ cresol added + amount naturally found from GC/MS analysis = total $p$-cresol in water sample). Utilization rate (in $\mathrm{g} \mathrm{l}^{-1} \mathrm{~h}^{-1}$ ) was divided into natural $p$-cresol concentration to estimate turnover time for phenolics in each environment sampled. Residence times were calculated from the starting and ending $\left[2,6-{ }^{3} \mathrm{H}\right]$-p-cresol concentrations using the following formula for exponential utilization:

$$
\tau=-\frac{t}{\ln \frac{S_{t}}{S_{0}}}
$$

where $t=$ time of incubation, $S_{t}=$ substrate concentration at time $t$, and $S_{0}=$ substrate concentration at time 0 . This calculation does not take into account the ambient level of $p$-cresol in the sample so it was calcu- lated only for comparison with other reported studies. Turnover times relate utilization rate to ambient concentration, so one must assume a constant utilization rate which is reasonable in a semi-stcady state system (i.e. chronic input). Since we assume there is a relatively constant input of phenolics in the environments tested, we also assume input to be relatively constant over short time scales.

Calculation of microbial abundance. Subsamples from seawater collected were amended to $2 \%$ with buffered formalin and stored refrigerated for no more than $4 \mathrm{~d}$ before enumeration by acridine orange direct count epifluorescent microscopy (Hobbie et al. 1977). A $t$-test was performed on data at the $99 \%$ level to determine confidence intervals.

\section{RESULTS}

Analysis of $\boldsymbol{p}$-cresol and other phenolics. Concentrations of $p$-cresol and total identifiable phenolics are shown in Table 1 . Concentrations of $p$-cresol ranged from 9.26 (Humboldt Bay) to $303 \mathrm{ng} \mathrm{l}^{-1}$ (White's Point Outfall). Total identified phenols ranged from 161 (Spanish Landing) to $1405 \mathrm{ng} \mathrm{l}^{-1}$ (White's Point Outfall). Phenols identified qualitatively were o-cresol, $\mathrm{m}$ cresol, and p-cresol, phenol, and catechol (Table 2).

Utilization rates and turnover times. Utilization rates of $p$-cresol are shown in Table 2. Rates ranged from 1.02 (Spanish Landing) to $35.5 \mathrm{ng} \mathrm{l}^{-1} \mathrm{~h}^{-1}$ (San Francisco Bay). Turnover times for $p$-cresol are also shown in Table 2. Turnover times were extremely rapid with the entire $p$-cresol pool estimated to be utilized in 1.7 (San Francisco Bay) to 37 h (Spanish Landing). Residence times ranged from 10 (San Francisco Bayl to 28 h (White's Point Outfall).

Bacterial abundance. Bacterial abundances were $3.00 \times 10^{9}$ (Sweetwater Channel), $2.91 \times 10^{9}$ (Spanish Landing), $9.55 \times 10^{8}$ (White's Point Outfall), $8.40 \times 10^{9}$ (San Francisco Bay) and $2.93 \times 10^{9}$ cells l$^{-1}$ (Humboldt Bay). Since incubation times were short $(6 \mathrm{~h})$, the assumption was made that no significant change in the population abundance occurred during the experiment.

\section{DISCUSSION}

Due to the large amounts of phenolic materials entering coastal marine environments, both as contaminants and as part of riverine humic materials, this study was undertaken to determine microbial utilization rates of a representative phenol, p-cresol. Probably the most intriguing findings are the relatively rapid utilization rates and short turnover times observed for 
Table 1 Total phenols identified, summer 1993

\begin{tabular}{|c|c|c|}
\hline Location & Phenol identified & $\begin{array}{c}\text { Concentration } \\
\left(\mathrm{ng} \mathrm{l}^{-1}\right)\end{array}$ \\
\hline $\begin{array}{l}\text { Sweetwater Channel } \\
4 \text { June }\end{array}$ & $\begin{array}{l}\text { Phenol } \\
o \text {-Cresol } \\
m \text {-Cresol } \\
\text {-Cresol } \\
\text { Catechol } \\
\text { 2-Chlorophenol }\end{array}$ & $\begin{array}{l}59.6 \pm 3.6 \\
25.2 \pm 1.0 \\
72.5 \pm 3.6 \\
45.0 \pm 1.3 \\
62.2 \pm 4.3 \\
24.7 \pm 1.7\end{array}$ \\
\hline Total & & $289 \pm 16$ \\
\hline $\begin{array}{l}\text { Spanish Landing } \\
4 \text { June }\end{array}$ & $\begin{array}{l}\text { Phenol } \\
o \text {-Cresol } \\
\text { m-Cresol } \\
\text { p-Cresol } \\
\text { Catechol }\end{array}$ & $\begin{array}{l}8.48 \pm 0.51 \\
9.01 \pm 0.36 \\
9.50 \pm 0.48 \\
37.6 \pm 1.1 \\
96.4 \pm 6.7\end{array}$ \\
\hline Total & & $161 \pm 9.2$ \\
\hline $\begin{array}{l}\text { White's Point Outfall } \\
9 \text { June }\end{array}$ & $\begin{array}{l}\text { Phenol } \\
o \text {-Cresol } \\
m \text {-Cresol } \\
p \text {-Cresol } \\
\text { Catechol }\end{array}$ & $\begin{array}{l}515 \pm 31 \\
234 \pm 9.3 \\
185 \pm 9.3 \\
303 \pm 9.1 \\
168 \pm 11\end{array}$ \\
\hline Total & & $1405 \pm 70$ \\
\hline $\begin{array}{l}\text { San Francisco Bay } \\
16 \text { June }\end{array}$ & $\begin{array}{l}\text { Phenol } \\
o \text {-Cresol } \\
m \text {-Cresol } \\
\text { p-Cresol } \\
4 \text {-Chloro3- } \\
\text { methylphenol }\end{array}$ & $\begin{array}{r}245 \pm 15 \\
63.7 \pm 2.5 \\
94.9 \pm 4.7 \\
61.1 \pm 1.8 \\
144 \pm 4.3\end{array}$ \\
\hline Total & & $609 \pm 28$ \\
\hline $\begin{array}{l}\text { Humboldt Bay } \\
17 \text { June }\end{array}$ & $\begin{array}{l}\text { Phenol } \\
\text { p-Cresol } \\
\text { Catechol }\end{array}$ & $\begin{array}{c}58.6 \pm 3.5 \\
9.26 \pm 0.28 \\
129 \pm 9.0\end{array}$ \\
\hline Total & & $197 \pm 12$ \\
\hline
\end{tabular}

$p$-cresol in all environments tested. We also speculate that utilization of 'refractory' freshwater and terrestrially derived humic materials by estuarine and marine microbial communities may occur.

The study sites ranged from near-estuarine conditions (San Francisco Bay and, in some respects, Hum- boldt Bay) to marine (White's Point Outfall) to slightly hypersaline (Sweetwater Channel in South San Diego Bay) environments, yet turnover time estimates ranged from only $1.7 \mathrm{~h}$ in San Francisco Bay to $37 \mathrm{~h}$ at Spanish Landing in San Diego Bay. These short turnover times (within a 15-fold range) are in sharp contrast to those of studies performed in environments on the east coast of the United States (Bartholomew \& Pfaender 1983, Palumbo et al. 1988). In those studies, freshwater, estuarine and marine sites were tested with ${ }^{14} \mathrm{C}$-m-cresol to determine utilization rates and turnover times. The authors found that turnover times for $m$-cresol were as much as 150 times faster in freshwater and estuarine sites compared to those of marine waters. Although our test substrate does not have the same substitution ( $p$ - vs $m$-) and cannot be directly compared, we are not aware of any published pathways for the biodegradation of cresol by marine bacteria. In our previous studies with natural populations, incubation with different cresol isomers demonstrated almost no variation in degradation rates (Boyd \& Carlucci 1993). Furthermore, cleavage tests (Ottow \& Zolg 1974) conducted on slow-growing marine isolates $\left(p^{-}, m\right.$ - and o-cresol, $500 \mu \mathrm{g} \mathrm{l}^{-1}$ as only carbon substrate) showed inconclusive results with neither ortho- nor meta- cleavage coloration observed (authors' unpubl. obs.).

Perhaps some of the differences in rate estimates in this study compared to the east coast work are due to the ability to measure ambient concentrations of the test substrate ( $p$-cresol) in the California coastal waters and relate this value to isotopic dilution. Also, in the present work, a tracer amount of $\left[2,6-{ }^{3} \mathrm{H}\right]-p$-cresol (specific activity about 3 orders of magnitude greater than available with ${ }^{14} \mathrm{C}$-labeled $p$-cresol) was added to test samples in a concentration no more than $10 \%$ of the natural or ambient $p$-cresol concentration to minimize microbial stimulation. Previous work indicates that taking isotope dilution into account gives more reliable utilization values (Carlucci et al. 1986).

Table 2. Concentration of $p$-cresol, total cresols and their microbial utilization rates, residence and turnover times, and percent $\left[2,6-{ }^{3} \mathrm{H}\right]-p$-cresol utilized at various coastal California (USA) sites

\begin{tabular}{|c|c|c|c|c|c|}
\hline Sample location & $\begin{array}{c}p \text {-Cresol } \\
\text { concentration } \\
\left({\left.\text { ng } 1^{-1}\right)}^{-1}\right.\end{array}$ & $\begin{array}{l}\text { Utilization rate } \\
\qquad\left(\mathrm{ng} \mathrm{l}^{-1} \mathrm{~h}^{-1}\right)\end{array}$ & $\begin{array}{l}\text { Residence time } \\
\text { p-cresol } \\
\text { (h) }\end{array}$ & $\begin{array}{l}\text { Turnover time } \\
\text { p-cresol } \\
(\mathrm{h})^{\mathrm{a}}\end{array}$ & $\begin{array}{c}{\left[2,6-^{3} \mathrm{H}\right]-} \\
p-\text { Cresol utilized } \\
(\%)^{\mathrm{b}}\end{array}$ \\
\hline Sweetwater Channel & $45.0 \pm 1.3$ & $1.56 \pm 0.23$ & $19 \pm 0.4$ & $28.9 \pm 5.8$ & 27 \\
\hline Spanish Landing & $37.6 \pm 1.1$ & $1.02 \pm 0.15$ & $20 \pm 0.4$ & $37.0 \pm 7.4$ & 26 \\
\hline White's Point Outfall & $303 \pm 9.1$ & $20.8 \pm 3.1$ & $28 \pm 0.6$ & $14.6 \pm 3.0$ & 19 \\
\hline San Francisco Bay & $61.1 \pm 1.8$ & $35.5 \pm 5.3$ & $10 \pm 0.2$ & $1.72 \pm 0.34$ & 46 \\
\hline Humboldt Bay & $9.26 \pm 0.28$ & $1.48 \pm 0.22$ & $17 \pm 0.3$ & $6.26 \pm 1.2$ & 29 \\
\hline
\end{tabular}


At the Southern California sites, utilization rates of p-cresol in water samples from San Diego Bay (Spanish Landing and Sweetwater Channel) were up to about 1 order of magnitude lower than those of the freshwater-influenced White's Point or more estuarine Northern California (San Francisco and Humboldt Bays) sites. In these San Diego Bay samples, turnover times were generally longer. The longest turnover time for $p$-cresol in this study was in Spanish Landing. Of the bay sites studied, San Diego Bay is least influenced by freshwater input. Salinities of 34.1 to $34.7 \%$ are normal for the southern parts of the Bay in summer (South Bay Dischargers 1990, 1991, 1992). Salinity appeared to play only a minor role in the p-cresol biodegradation in this work since rates were within 1 order of magnitude in aii the environmenis lesied (Table 2). In stüdies performed on the east coast of the United States (Bartholomew \& Pfaender 1983, Palumbo et al. 1988), increases in salinity correlated with concurrent decreases in utilization rates for $m$-cresol, making turnover times at high salinity sample sites up to 150 times higher. p-Cresol turnover times for San Diego Bay were on the order of $1 \mathrm{~d}$. On these time scales, tidal flushing may be a significant factor in addition to biodegradation in determining the ambient concentration of phenolic compounds within the Bay. Increased river flow during winter may add appreciable amounts of humic materials to San Diego Bay and also lower the salinity. Utilizers of phenolic materials may become a larger proportion of the microbial population during times when this humic input is high, possibly increasing the utilization rate and shortening turnover time. Input of phenolics in San Diego Bay is most likely from industrial dischargers (South Bay Dischargers 1990, 1991, 1992).

The White's Point Outfall site is an area where municipal waste from Los Angeles County is discharged into the coastal ocean. Initial dilution rates of the effluent are on the order of 100:1 within tens of meters of the outfall diffusers (Hendricks 1976, 1977). Near this outfall, turnover time of $p$-cresol was about 15 h (Table 2); therefore, assuming a constant utilization rate, p-cresol disappearance would occur much more rapidly as dilution increases. It is reasonable to conclude that marine bacteria play a significant role along with dilution (at least beyond detection levels) in defining the phenolic characteristics of waters off White's Point Outfall.

Curiously, the utilization rate of $p$-cresol in the San Francisco Bay sample showed a turnover time that was actually shorter than the incubation time $(1.7$ and $6 \mathrm{~h}$. respectively). This would indicate (assuming a linear rate) complete utilization of the added $\left[2,6-{ }^{3} \mathrm{H}\right]-p-$ cresol 3 times over. However, only $46 \%$ of the added p-cresol was utilized even after $6 \mathrm{~h}$ of incubation
(Table 2). Similarly, in the White's Point Outfall and the Humboldt Bay samples, the percent utilization extrapolated over 6 h incubation periods does not fall within the turnover times (White's Point: $19 \%$ utilized in $6 \mathrm{~h}$, 15 h turnover time; Humboldt Bay: $29 \%$ utilized in $6 \mathrm{~h}$, 6 h turnover time).

Several explanations may be offered to reconcile the observed rate measurements and isotope imbalance: (1) other phenolic materials (identified by chemical analysis) competed with $p$-cresol for the enzymes responsible for utilization, or (2) there was a production of $p$-cresol (or comparable phenol) within the incubation vessel at a rate able to sustain the rapid turnover and further dilute the added ${ }^{3} \mathrm{H}$-labeled substrate. In the case of explanation (1), it is reasonable to assume that enzymos able to break down p-cresol might also have some specificity for other phenolic type compounds (Stanier \& Ornston 1973), in this case phenols, cresols, and possibly catechol. If this is true, it might account for some of the $\left[2,6-{ }^{3} \mathrm{H}\right]-p$-cresol found remaining in the sample after incubation. However, it should be pointed out that if there was considerable cross reactivity associated with the enzymes responsible for $p$-cresol utilization, other competing compounds should have been considered when calculating initial isotope. These adjusted rates would make turnover times for total phenols the same as originally calculated for $p$-cresol (rate divided into ambient concentration). In other words, the utilization rate would become proportionally faster (greater isotope dilution) and the ambient concentration would be proportionally higher (total phenols as opposed to just p-cresol).

San Francisco Bay, Humboldt Bay, and the White's Point Outfall sites are all exposed to considerable freshwater input: the Mad River in Humboldt Bay, the Sacramento and San Joaquin Rivers in San Francisco Bay, and the wastewater of Los Angeles County at White's Point Outfall. The San Diego Bay sites are generally exposed to very little freshwater input especially during summer when this work was performed. As mentioned earlier, the turnover times for Humboldt and San Francisco Bays were similar to or lower than the incubation time $(6 \mathrm{~h})$ used for the uptake study, 6.3 and $1.7 \mathrm{~h}$, respectively. However, utilization of added $\left[2,6-{ }^{3} \mathrm{H}\right]$-p-cresol was only 29 and $46 \%$, respectively. At White's Point Outfall, turnover time for $p$-cresol was $15 \mathrm{~h}$, yet only $19 \%$ of the added $\left[2,6-{ }^{3} \mathrm{H}\right]-p$-cresol was utilized. At that rate of utilization, $30 \mathrm{~h}$ of incubation would be required for all of the added $\left[2,6-{ }^{3} \mathrm{H}\right]-p$ cresol to be utilized. In contrast, at Sweetwater Channel and at Spanish Landing, 27 and $26 \%$ of the added $\left[2,6-{ }^{3} \mathrm{H}\right]$-p-cresol was utilized during 6 h of incubation. Turnover times were 29 and 37 h, respectively. At both these sites, the added substrate would be utilized within the turnover time. 
Because the identified phenols in all samples were qualitatively similar (phenol, cresol isomers, and catechol were the only other identified phenols), any enzyme cross-reactivity might have occurred in approximately the same proportion in each of the samples. However, only those samples taken from sites where freshwater input was high (containing freshwater and terrestrial humic materials) showed substantial 'additional' dilution of the isotope during the incubation period. We propose that in the areas where freshwater input is significant, $p$-cresol (or similar simple phenolics) may, in fact, represent an intermediate in the breakdown of more complex freshwater humic materials (containing phenolic moieties) such that a flux of phenolic materials is maintained during incubation. This flux might essentially 'dilute' the added isotope during the course of incubation such that the proportion of $\left[2,6-{ }^{3} \mathrm{H}\right]-p$-cresol to ambient $p$-cresol would decrease over time. This phenomenon was not observed in the San Diego Bay samples (little freshwater input) and 'no flux' state (Fig. 2).

As mentioned earlier, it is established that there is a rapid degradation of freshwater humic materials traveling through estuarine environments toward the sea. Because these phenolic moieties are quickly removed and the results of this study indicate rapid microbial utilization of phenolic substrates, it is plausible to suggest biological breakdown of humic materials plays a part in producing a flux of $p$-cresol or similar phenolic. In the incubating sample this flux would continually cause an isotope dilution and the tracer would not be fully utilized within the calculated turnover time (Fig. 2).

A number of explanations have previously been postulated to account for the rapid loss of 'biologically refractory' freshwater humic materials and riverine $O C$ in estuaries. Bulk sedimentation (Ittekkot \& Haake 1990), aggregation (Ogura 1977. Wakeham et al. 1984), and sorption (Hedges 1978) are removal mechanisms traditionally proposed for humic materials in coastal and open ocean waters. However, most chemical and isotopic evidence suggests a predominantly marine origin for sedimentary and dissolved OC even in coastal environments (Nissenbaum \& Kaplan 1972). Recently, photodegradation of humic materials in marine waters has been proposed as a major mechanism of $\mathrm{OC}$ removal since humic materials are photo-converted to low molecular weight, readily bio-utilizable organics (Kieber et al. 1989, 1990). It has been further postulated that photodegradation may account for the breakdown of half of the humic material in the upper $20 \mathrm{~m}$ of the mixed layer within 5 yr. In turbulent areas such as the Columbia River, northwestern United States, where at certain times of year the river plume may extend for miles into the sea, rapid mixing and estuarine flushing may shorten the residence time of riverine water in the
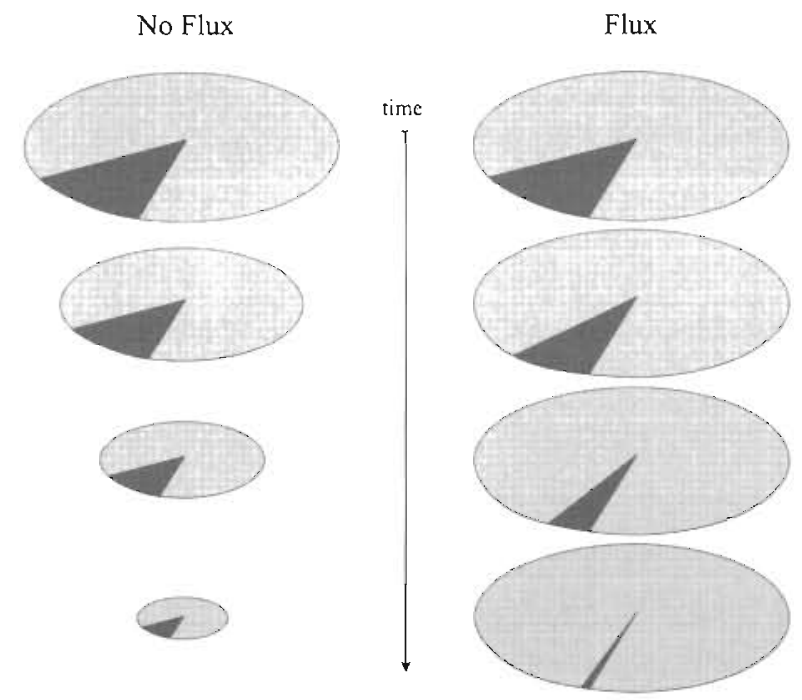

Proportion of labeled tracer

to ambient $p$-cresol concentration remains constant over time

Proportion of labeled tracer to ambient $p$-cresol concentration decreases over time

Fig. 2. Schematic representation of 'No Flux' and 'Flux' states during incubation of samples. See text for discussion

surface layer (Mantoura \& Woodward 1983). Photodegradation was not a factor in the present work since all incubations were done in the dark.

The long standing association of humic materials with biological refractance has recently come under reevaluation. Observations show that humic fractions of organic matter in freshwater systems are, in fact, utilizable by indigenous microbes (Moran \& Hodson 1990, Tranvik 1990). Also recently, humic materials from soil (Carlsson \& Granéli 1993) and freshwater (Carlsson et al. 1993) environments have been used to assess humic material utilization in marine systems. Marine bacterial biomass increased significantly after the addition of allochthonous humic material to incubation vessels. These findings also present evidence for the liberation of nutrients ( $\mathrm{N}$ and $\mathrm{P}$ ) from allochthonous humic materials. Turnover times and 'additional' isotope dilution observed in the present study indicate that rapid utilization of phenolics and the possible conversion of humic materials into more readily utilizable phenolic constituents might be an important mechanism in estuarine environments. Since flux values appear high, microbial utilization of phenolic/humic materials may be a significant factor affecting coastal water chemistries.

In summary, microbial degradation of phenolic materials, both anthropogenic and possibly those derived from humic type materials, plays a major role along with processes such as photodegradation, flocculation, sedimentation, dilution, and mixing in defining the chemical nature of estuarine and coastal marine waters. 
Acknowledgements. Research was funded in part by a grant from the National Sea Grant College Program, National Oceanic and Atmospheric Administration, U.S. Department of Commerce, under grant number NA89AA-D-SG138, project number R/CZ-98 through the California Sea Grant College, and in part by the California State Resources Agency. The views expressed herein are those of the authors and do not necessarily reflect the views of NOAA or any of its subagencies. The U.S. Government is authorized to reproduce and distribute for governmental purposes. Funds and logistical support were also provided by the Office of Naval Research under grant N00014-87-K-0148 and by the Marine Life Research Group at Scripps Institution of Oceanography. Special thanks are given to the County Sanitation District of Los Angeles County and the crew of the vessel RV 'Ocean Sentinel

\section{LITERATURE CITED}

Abrahamsson K, Klick S (1991) Degradation of halogenated phenols in anoxic natural marine sediments. Mar Pollut Bull 22:227-233

Bartholomew GW, Pfaender FK (1983) Influence of spatial and temporal variations on organic pollutant biodegradation rates in an estuarine environment. Appl Environ Microbiol 45:103-109

Boyd TJ (1994) Identification and quantification of mono-, di-, and tri-hydroxybenzenes (phenols) at trace concentrations in seawater by aqueous acetylation and GC/MS analysis J Chromatogr 662:281-292

Boyd TJ, Carlucci AF (1993) Degradation rates of substituted phenols by natural populations of marine bacteria. Aquat Toxicol 25:71-82

Boyd TJ, Carlucci AF (1994) Use of a ${ }^{3} \mathrm{H}$-labeled substrate to measure microbial biodegradation in marine waters J Microbiol Meth 20:11-22

Carlson DJ (1982) Surface microlayer phenolic enrichments indicate sea surface slicks. Nature 296:426-429

Carlson DJ, Mayer LM (1980) Enrichment of dissolved phenolic material in the surface microlayer of coastal waters. Nature 286:482-483

Carlsson P, Granéli E (1993) Availability of humic bound nitrogen for coastal phytoplankton. Estuar Coast Shelf Sci $36: 433-447$

Carlsson P, Segatto AZ, Granéli E (1993) Nitrogen bound to humic matter of terrestrial origin - a nitrogen pool for coastal phytoplankton? Mar Ecol Prog Ser 97:105-116

Carlucci AF, Craven DB, Robertson KJ, Williams PM (1986) Surface-film microbial populations: diel amino acid metabolism, carbon utilization, and growth rates. Mar Biol 92: 289-297

Charriere B, Gadel F, Serve L (1991\} Nature and distribution of phenolic compounds in water and sediments from Mediterranean deltaic and lagunal environments. Hydrobiologia 222:89-100

Deuser WG (1988) Whither organic carbon? Nature 332 : $396-397$

Ertel JR, Hedges JI, Devol AH, Richey JE, Ribeiro M, Ribeiro G (1986) Dissolved humic substances of the Amazon River system. Limnol Oceanogr 31:739-754

Goni MA, Hedges JI (1990) Potential applications of cutinderived cupric oxide reaction products for discriminating vascular plant sources in natural environments. Geochim Cosmochim Acta 54:3073-3082

Hedges JI (1978) The formation and clay mineral reactions of melanoidins. Geochim Cosmochim Acta 42:69-76
Hendricks T (1976) Measurements of subthermocline currents. Annual Report 1976 Long Beach, Southern California Coastal Water Research Project, Long Beach, CA, p 63-70

Hendricks T.J (1977) In situ measurements of initial dilution. Annual Report 1977 Long Beach, Southern California Coastal Water Research Project, Long Beach, CA, p 41-50

Hobbie JE, Daley RJ, Jasper S (1977) Use of Nuclepore filters for counting bacteria by fluorescence microscopy. Appl Environ Microbiol 33:1225-1228

Ittekkot V. Haake B (1990) The terrestrial link in the removal of organic carbon in the sea. In: Ittekkot $V$ (ed) Facets of modern biogeochemistry. Springer-Verlag, New York, p $318-325$

Jasper JP, Gagosian RB (1993) The relationship between sedimentary organic carbon isotopic composition and organic biomarker compound concentration. Geochim Cosmochim Acta 57:167-186

Kalinowski E, Blondeau R (1986) Estuarine sedimentary humic material. Vie Mar 7:61-68

Kieber DJ, McDaniel J, Mopper K (1989) Photochemical source of biological substrates in sea water: implications for carbon cycling. Nature 341:637-639

Kieber RJ, Zhou X, Mopper K (1990) Formation of carbonyl compounds from UV-induced photodegradation of humic substances in natural waters: fate of riverine carbon in the sea. Limnol Oceanogr 35:1503-1515

King GM (1986) Inhibition of microbial activity in marine sediments by a bromophenol from a hemichordate. Nature 323:257-259

King GM (1988) Dehalogenation in marine sediments containing natural sources of halophenols. Appl Environ Microbiol 54:3079-3085

Knuutinen JS, Mannila JP (1991) High-performance liquid chromatographic study on oxidation products of lignin and humic substances. Water Sci Technol 24:437-440

Kozitskaya VN (1984) Phenolic compounds of algae and their physiological role. Hydrobiol J 3:54-63

Malcolm RL (1990) The uniqueness of humic substances in each of soil, stream and marine environments. Analyt Chim Acta 232:19-30

Mantoura RFC, Woodward EMS (1983) Conservative behaviour of riverine dissolved organic carbon in the Severn Estuary: chemical and geochemical implications. Geochim Cosmochim Acta 47:1293-1309

Marley NA, Gaffney JS, Orlandini KA, Picel KC, Choppin GR (1992) Chemical characterization of size-fractionated humic and fulvic materials in aqueous samples. Sci Total Environ 113:159-1.77

Meyers-Schulte KJ, Hedges JI (1986) Molecular evidence for a terrestrial component of organic matter dissolved in ocean water. Nature 321:61-63

Moran MA, Hodson RE (1990) Bacterial production on humic and nonhumic components of dissolved organic carbon. Limnol Oceanogr 35:1744-1756

Mulholland PJ, Olsen CR (1992) Marine origin of Savannah River estuary sediments: evidence from radioactive and stable isotope tracers. Estuar Coast Shelf Sci 34:95-107

Nissenbaum A, Kaplan IR (1972) Chemical and isotopic evidence for the in situ origin of marine humic substances. Limnol Oceanogr 17:570-582

Ogura N (1977) High molecular weight organic matter in seawater. Mar Chem 5:535-549

Ottow JCG, Zolg W (1974) Improved procedure and colorimetric test for the detection of ortho-and meta-cleavage of protocatechuate by Pseudomonas isolates. Can J Microbiol 20:1059-1061

Palumbo AV, Pfaender FK, Paerl HW (1988) Biodegradation of 
NTA and $m$-cresol in coastal environments. Environ Toxicol Chem 7:573-585

South Bay Dischargers (1990) Receiving water monitoring program. Kinnetic Laboratories, Inc, San Diego, CA

South Bay Dischargers (1991) Receiving water monitoring program. Kinnetic Laboratories, Inc, San Diego, CA.

South Bay Dischargers (1992) Receiving water monitoring program. Kinnetic Laboratories, Inc, San Diego, CA

Stanier RY, Ornston LN (1973) The b-ketoadipate pathway. Adv Microb Physiol 9:89-151

Steinberg PD (1989) Biogeographical variation in brown algal polyphenolics and other secondary metabolites: comparison between temperate Australasia and North America. Oecologia 78:373-382

Steinberg SM, Venkatesan MI, Kaplan IR (1987) Organic geo-

Responsible Subject Editor: F. Azam, La Jolla, California, USA chemistry of sediments from the continental margin off southern New England, USA, Part 1, Amino acids, carbohydrates and lignin. Mar Chem 21:249-265

Tranvik LJ (1990) Bacterioplankton growth on fractions of dissolved organic carbon of different molecular weights from humic and clear waters. Appl Environ Microbiol 56: $1672-1677$

US EPA (United States Environmental Protection Agency) (1992) Toxic release inventory, EPA 700/C-92-002, September 1992. US EPA, Office of Pollution Prevention and Toxics, Washington, DC

Wakeham SG, Lee C, Farrington JW, Gagosian RB (1984) Biogeochemistry of particulate organic matter in the oceans: results from sediment trap experiments. Deep Sea Res 31: 509-528

Manuscript first received: April 16, 1996

Revised version accepted: August 28, 1996 